\title{
МІСЦЕ КРИМІНАЛЬНОГО РАДИКАЛІЗМУ У ПОНЯТІЙНО-КАТЕГОРІАЛЬНОМУ АПАРАТІ КРИМІНОЛОГї̈
}

\author{
МАСЛОВА Наталія Григорівна - кандидат юридичних наук, докторант \\ (Харківський національний університет внутрішніх справ) \\ https://orcid.org/0000-0002-9009-1254 \\ DOI:10.32782/EP.2020.1.14
}

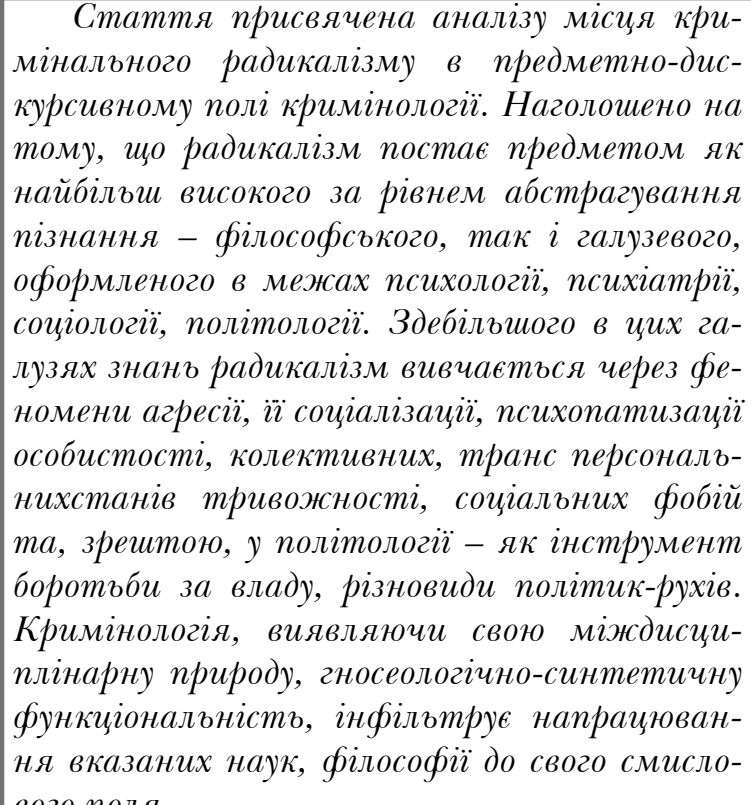
вого поля.

Доведений наскрізний характер феномену радикалізму для всієї структури предмету кримінологї: він присутній у загальному вченні про криміногенну детерміначію, особистість злочиния, механізм індивідуальної злочинної поведінки, віктимологї, а також у низиі складових особливої частини кримінологї (бонові для злочинності явища, політична, агресивно-насильницька, профбесійна, пенітенціарна, молодіжна злочинність тощз).

Наголошено на гносеологічній бінарності радикалізму: він розглядеться $і$ як суто криміногенний бактор, $i$ як змішаний кримінально-криміногенна практика-бактор; $i$ як об'єкт пізнання, $і$ як гносеологічний інструмент, завдяки якому поглиблюється пізнання детерміначійной природи злочинності, в тому иислі й позарадикальної феноменологї. Запропоновано вихідні теоретичні передумови для розробки окремої теорії детермінаиіi злочинності - теорії радикалізащї. Доводиться, що без кримінально-радикального сегменту дискурсивно-комунікативна теорія детерміначї злочинності не може претендувати на завершеність. Теорія радикалізаиій виявляе потениійно важливі (з високим евристичним потенціалом) пізнавально-логічні зв'язки з теоріями стигматизацй, низкою психологічних теорій детерміначї̈ злочинності.

Ключові слова: кримінальний радикалізм, кримінологія, детерміначія, злочинність, злочин, механізм, особистість.

\section{Актуальність теми}

Необхідність визначення місця кримінального радикалізму у понятійно-категоріальному апараті кримінології полягає у тому, що, будучи постійно присутнім у сфері людської діяльності, соціальних практик, радикалізм - єдиний феномен з тих, які досліджуються кримінологією на рівні окремого предмету, що не має свого однозначного змістовного насичення. Навіть ті феномени, які характеризуються варіативністю у правових оцінках (наприклад, політична злочинність), мають відповідні гносеологічні межі, що визначаються принаймні внутрішньою телеологічною установкою відпо- 


\section{Кримінальне право, кримінальний процес та криміналістика}

відних практик. Радикалізм же, натомість, не має навіть єдиної цільової настанови. Як таку не можна визнати і прагнення до змін. Змінюється все і завжди, що відповідає діалектиці руху. Стан спокою - абстракція, статична модель, що слугую пізнавальним цілям у ретроспекції. Тож і прагнення до змін є внутрішньою іманентною рисою будь-якої усвідомленої, вольової поведінки. Єдине, що вирізняє радикалізм, - форма: агресивний драйв, що виражає безкомпромісну соціальну боротьбу. Цією формою руху, аномально активною циркуляцією людської енергетики за позаконвенційними траєкторіями, просякнутий весь соціальний ландшафт, що, певна річ, не може не накладати відбиток і на характер злочинності, i на ступінь інтенсивності іiі відтворення, і на іiі детермінаційний комплекс.

Кримінологічні проблеми поширення кримінального радикалізму неодноразово ставали предметом наукових праць під авторством О. М. Бандурки, Ю. Б. Данильченка, В. О. Глушкова, С. Ф. Денисова, В. П. Емельянова, А. Ф. Зелінського, Н. А. Зелінської, О. М. Костенка, О. М. Литвинова, Г. В. Маляр, Ю. В. Орлова Е. А. Стрельцова та інших вчених. Визнаючи їх внесок у наукову розробку цієї проблематики, тим не менш слід визнати і те, що й досі у вітчизняній науці не визначено місце феномену кримінального радикалізму у категоріально-понятійному апараті кримінології, у зв’язку 3 чим зберігається певна доктринальна невизначеність, гносеологічна розгубленість, перепони на шляху до розробки ефективних кримінально-превентивних, системних заходів.

Мета статті - визначити та охарактеризувати місце кримінального радикалізму у понятійно-категоріальному апараті кримінології через встановлення відповідних предметно-гносеологічних зв'язків.

\section{Виклад основного матеріалу}

Наявні напрацювання філософського, соціологічного та політологічного характеру про природу радикалізму (як акту агресії, насильства, інструменту політики, крайнього ступеня соціальної тривожності тощо) дають підстави для твердження про розпорошеність цього феномену предметною тканиною кримінології. Водночас фіксується найбільш визначена його присутність в окремих проблемах особливої частини кримінологічної доктрини - агресивно-насильницькій та політичній злочинності. Водночас, таке становище не є в повній мірі адекватним та не задовольняє запити нашого дослідження. Справа в тому, що первинно зроблені нами методологічні зауваження не залишають сумнівів у приналежності радикалізму до антропологічних констант. А якщо це так, то він (радикалізм) має проявитися не тільки і не стільки у питаннях особливої частини кримінології, скільки загальної, відобразитись у базових знаннях про природу людини, в тому числі й злочинця, генези злочину й злочинності. Тому є потреба в уточненні наявних передумов, у прирості знань про місце радикалізму в понятійно-категоріальному апараті (за яким стоїть конкретне предметне поле) кримінології.

Звертаючись до визначення місця радикалізму в предметній структурі загальної частини кримінології, зауважимо, що розуміння злочинності, на нашу думку, доповнити радикалізмом ледве чи вдасться. Коли йдеться про загальне поняття злочинності, то її ознаки мають характеризуватися універсальністю, всеосяжністю щодо повного обсягу відповідного поняття і явища (феномен), що ним позначається. Радикалізм хоча і визначається антропологічною константою, проте не тотальною. Вона не може бути визнана однією з базовим характеристик злочинності. Цілком зрозуміло, що необережні, корупційні, наркозлочини й низка інших злочинів не мають нічого спільного $з$ радикалізмом. Як злочин - не ознака людини, злочинність - не ознака всієї цивілізації, так і радикалізм - не може бути ознакою всієї злочинності. Аогічні обсяги їх понять частково перетинаються. Ця думка - очевидна та не вимагає додаткових пояснень. Тож у загальному вченні про злочинність радикалізм себе не проявляє.

Детермінація злочинності - предметний сегмент 3 ширшою кореневою системою 
(відповідь на питання «як?» завше ширша, розлогіша за відповідь на питання «що?», адже, окрім опису, пояснення явища передбачає й опис і пояснення взаємодії, іiі факторів), у ризоматичній структурі якої радикалізм виявляється органічним феноменом. Допіру поставити питання про розробку теорії радикалізащіи як складову загального вчення про детермінацію злочинності в частині окремих комплексних теорій криміногенної детермінації.

Як і будь-яка інша окрема теорія криміногенної детермінації, теорія радикалізації претендуватиме на опис механіки відтворення не всієї злочинності, а лише тієї iii частини, в якій соціальна пасіонарність укладається у концепти й реалізується у заборонених кримінальним законом формах діяльності, практиках. Радикалізм для 3лочинності повинен бути помислений своєрідним антропогенетичним modusoperandi. Належить з'ясувати, за яких умов і якими комунікативними каналами, в якому дискурсивному фоні відбувається: а) радикалізація докси, дискурсу; б) їх перехід у площину соціальних практик як радикалізму, так і інших злочинів; в) криміналізація радикалізму. Остання ланка 6 найбільш наближеною у детермінаційному комплексі до безпосередньої злочинності.

Відтак уже зараз можливо зафіксувати пізнавальну бінарність теорії радикалізації, що відображає роздвоєння радикалізму на етапі трансформації мислення й дискурсу у діяльність на криміногенний бактор та кримінально-криміногенну практику-ббактор. Сутність першого - у продукуванні широкого спектру позарадикальної злочинності, але такої, що зумовлена радикальним мисленням, мовою ворожнечі, хейтерством, агресивним афіліаторством як такими. Сутність другого - у детермінації кримінального радикалізму, злочинів радикальної спрямованості та подальшого, механізмами криміногенної самодетермінації, поширення похідних видів кримінальної активності: від державної зради до корупційних злочинів.

За такого підходу феномен радикалізму фактично постає інструментом деконструкції соціальної дійсності у їі кримінологічно- му осмисленні, сприйнятті як детермінаційного комплексу злочинності. У цьому контексті правим, на наш погляд, є О. М. Аитвинов, коли вказує, що з урахуванням комплексного міждисциплінарного, інтегративного характеру самої концепції кримінологічної детермінації ії наскрізний аналіз є архіскладним та об'ємним завданням. Його можна вирішити за допомогою фрагментації відповідного знання, деконструкції цілісного концепту за рахунок специфікації окремих його компонентів. Одним із них 6 час[1, с. 156]. Із цим важко не погодитись. Втім, радикалізм, на відміну від часу є, певна річ, не настільки фундаментальною онтологічною категорією. Однак, і час у ньому проявляється у модусах cogito, набуваючи вельми специфічних характеристик. Критерії ж реконструкції дійсності є суто телеологічними, спираються на визначені цільові настанови, можуть і повинні мати комплексний характер. Цим критеріям цілком відповідає радикалізм. Саме тому він може розглядатися і як спосіб пізнання детермінації злочинності.

Отже, радикалізм у цьому ключі розглядається не тільки і не стільки як об'єкт пізнання, скільки як гносеологічний інструмент, завдяки якому поглиблюється пізнання детермінаціної природи злочинності, і не тільки кримінального радикалізму. Таким чином зміщується акцент кримінологічного дослідження з самого радикалізму на його криміногенні властивості, що, зрозуміла річ, передбачає наявність досить повного, попередньо сформованого уявлення про зміст радикалізму, тобто як про об'єкт, а не метод. Таким чином, формується перша ланка міжпредметних зв'язків загальної та особливої частин кримінології в контексті виявлення місця та пізнавального значення радикалізму в категоріально-понятійному апараті цієї науки: взаємовідношення детермінант злочинності та бонових для злочинності явищ у розрізі феномену радикалізму.

Окремо варто наголосити на тому, що дослідження мови ворожнечі як дискурсивного ядра кримінального радикалізму має доповнити й положення дискурсивнокомунікативної теорії детермінації злочинності[2, с. 23-32; 3, с. 126-136; 4, с. 176-184 


\section{Кримінальне право, кримінальний процес та криміналістика}

та ін.] у частині поглиблення розуміння механізмів впливу особливої системи мемів, категорій, пов'язаних 3 ними ефектів постпам'яті на радикалізацію суспільних настроїв, практик. Мова ворожнечі (ненависті) у кожного народу, спільноти - своя. Чим більшими є критерії можливої ідентичності - тим більший простір для такої мови. Чим більш прив'язаними є спільноти до історії - тим потужнішим є радикально-криміногенний потенціал соціальної міфологізації та стимуляції постпам'яті.

3 іншого боку, і криза ідентичності, і несформованість історичної пам'яті утворюють «вільні радикали», заповнення та використання яких - справа безструктурного управління, маніпуляції масовою свідомістю, іiі міфологізації. Кожна людина - наголошував всесвітньовідомий невропатолог О. Сакс - це історія. Щоб бути собою, слід собою володіти - зберігати, а за потреби, відновлювати історію власного життя, «пригадувати» себе, свою особисту драму, сюжет, образ. Ця невпинна внутрішня оповідь noтрібна людині, щоб зберігати власну ідентичність, своє «я». Позбавлення безперервності, невимущеної плинності внутрішньої історії, що викликається розладами пам'яті, спричиняє до занурення у шалений наративний потік, у псевдоісторії[5, с. 144].

Bоістину: святе місце пустим не буває. Й незаповнені модуси соціальної (історичної, національної, культурної і в інших подібних конотаціях) пам'яті - лакуни, що досить легко й невимушено використовуються, адаптуються під запити дезадаптованої, фрагментованої особистості у символічно ворожому середовищі. Набагато простіше повірити (увірувати) у свою велич чи власну праведну жертовність, несправедливу пригніченість, аніж виробити легальний, функціонально належний механізм адаптації до соціального середовища, імпортувати до власного тіла імперативів домінантні соціальні конвенції конкретного контексту життєдіяльності. А це - механіка гідності та ресентименту - радикальна гра 3 ідентичностями чи гра ідентичностей 3 «вільними радикалами». Так чи інакше, але мова, дискурс постають у цій механіці провідниками людської енергетики, «лінзами» розсіяної пасіонарності, що фокусують їі до крайньої, безальтернативної визначеності, забезпечують згущення й цілепокладання волі на відповідні соціально значущі, часто злочинні діï.

3 цього випливають два проміжні висновки. По-перше, без кримінально-радикального сегменту дискурсивно-комунікативна теорія детермінації злочинності не може, на нашу думку, претендувати на завершеність. По-друге, теорія радикалізації виявляє потенційно важливі (з високим евристичним потенціалом) пізнавально-логічні зв'язки з теоріями стигматизації, низкою психологічних теорій детермінації злочинності. Радикалізм, таким чином, знову виявляє свої риси як епістемологічно наскрізної категорії для кримінологічного понятійнокатегоріального апарату.

Дотичним до теорії криміногенної детермінації є вчення про особистість злочиния та індивідуальну злочинну поведінку. У цих сегментах кримінологічного знання радикалізм так само віднаходить своє місце, демонструючи приналежність до категорії саме (перш за все) загальнотеоретичного знання. Водночас, не можна не помітити, що рівень аналізу знижується від загального до індивідуального, проте типового. Мова йде про місце радикалізму у структурах особистості злочинця та механізмі окремого злочину.

Цілком зрозуміло, що у своїй багатомодусній структурі й варіативності радикалізм не може бути ідентифікований у структурі особистості. Натомість окремі його вузли, поведінкові прояви не можуть не брати своє начало від особистості. I в цьому сенсі кожна людина здатна стати радикалом. Питання лише в умовах середовища, при збігу яких відповідні емоційно-вольові якості формують основний поведінковий фактор кримінально-радикального прояву. Отже, саме емоційно-вольова сфера в більшій мірі визначає можливість спосіб, крайню, радикальну форму дії в конкретних обставинах. На варто, гадаємо, додатково вказувати на значення типу темпераменту, на силу системних і базальних вольових якостей, а також, що немаловажно, на розлади емоційної сфери, психічні розлади загалом, стресові, реактивні та кумулятивні патопсихічні ста- 
ни (посттравматичні стресові розлади, депривація, депресія, тривожність, фрустрація, відчуженість, дезадаптивні стани тощо) які виявляють взаємозв'язок з агресивністю та агресією (зазначені аспекти особистості загалом і злочинця зокрема неодноразово ставали предметом дослідження як у загальній психології, психіатрії, так і у патопсихології, кримінології; відомі широкому загалові праці А. Г. Амбрумової, Ю. М. Антоняна, В. С. Емінова, В. П. Емельянова,В. М. Кудрявцева, О. М. Костенка, С. Г. Самовичева та інших учених). При цьому тривожність має зв'язуючий характер, постаючи як фактором самостійної етіології, так і симптомом (фрустрації, відчуження тощо), але неодмінно характеризується потужним впливом на параметри безпеки особистості. Остання в значній мірі виявляється через зв'язки групової ідентичності і приналежності, що мають прямий «вихід» на радикалізм.

Разом 3 тим ця аналітична схема демонструє радше специфіку генези кримінально-радикальної поведінки на індивідуальному рівні, візуалізуючи іiі детермінаційні зв'язки зі станами тривожності і суміжними особистісними факторами. Натомість, дещо специфікуючи концепцію академіка О. М. Костенка[6; 7, с. 70-75], вважаємо за можливе вести мову і про особливий модусрадикальної сваволі, що визначає готовність (з урахуванням інтелектуальних (ілюзії), досвідно-світоглядних, вроджених якостей) діяти всупереч соціальним конвенціям. Цей модус знаходиться на «полюсах» комплексу сваволі та ілюзій і визначає можливість діяти крайнім, контрконвенційним способом, незважаючи на високий ризик особистісних і колективних втрат.

У структурі ж механізму індивідуальної злочинної поведінки феномен радикалізму має і очевидні проявлення, і неочевидні. До перших можна віднести швидкість прийняття рішення про вчинення конкретного агресивно-насильницького злочину, обрання способу, реалізації рішення, що здебільшого супроводжується активним протистоянням фізично визначеним, дегуманізованим (часто й деперсоналізованим) опонентам. Але це - очевидний, явний бік наскрізної властивості радикалізму, що виникає з модусу радикальної сваволі. Остання $є$ домінантою у структурі чинників вказаного механізму та набуває первинного характеру щодо об’єкту енергетичної “розрядки» (у категоріях «гідравлічної» моделі агресії К. Лоренца).

Неявна ж присутність радикалізму у механізмі кримінальної активності виявляється у структурах віктимності й віктимізацй, які вмонтовуються в процес криміналізації особистості. Йдеться про комплекс «жертви злочинця». Одним із механізмів закріплення стандартів насильства, наголошують Х. Курі та В. I. Поклад, може бути попередня віктимізація особистості[8, с. 16]. На цьому ж наголошує і С. Сміт, вказуючи, що в якісних характеристиках груп злочинів та груп жертв багато спільного[9, с. 98; 10, с. 76]. Більше того: здійснені нами невключні спостереження за розгортанням радикальних рухів, вивчення результатів низки досліджень засвідчують, що для радикального руху обов'язковим елементом його інтенсифікації й перехід у фазу кримінальних практик, власне кримінального радикалізму, 6 афіліація радикалів $з$ жертвами діяльності опонентів, соціального порядку як такого. Тож кримінальна радикалізація особистості та ії діяльності безпосередньо пов'язана з ії об'єктивною та/або суб'єктивною віктимізацією.

Радикал завжди і перш за все є жертвою. Такий статус «розв'язує руки» на найбільш агресивні й насильницькі дії, що постають у наративах радикалізму як акти самозахисту, захисту вітальних інтересів своєї групи від дійсних чи удаваних (або ж у їх комбінації) загроз.Відтак, радикалізм на масовому рівні його відтворення завжди супроводжується конструюванням, підтримуванням дієвості деяких віктимінальних порядків, які фактично відіграють функцію ресентиментарного середовища. Останнє не може відбутися (а радикалізм реалізуватися) поза віктиманльним порядком.

У цьому аспекті слушними видаються ідеї професора О. М. Литвинова, який пропонує виділити, побачити «кримінологічним оком» у дійсності особливий, віктимальний порядок. Новий Віктимальний Порядок, констатує дослідник, - це вже 


\section{Кримінальне право, кримінальний процес та криміналістика}

реальність, яка, проте, як справжній симулякр намагається довести власну нереальність[11, с. 173]. Ж. Бодрійяр пише: «Віктимальність йде рука в руку з правами людини як єдина заупокійна ідеологія»[11, с. 173]. Суспільство визначається. 3 переходом до нової епохи, у якій цінності є реалізованими й тому неактуальними, те, що вважається соціальною структурою, соціальною реальністю, втрачає стійкість і визначеність, стає ефемерним, нестабільним, парадоксальним, ірраціональним або взагалі зникає. Суспільство не зникає, хоча перестає бути реальним. Оскільки суть сучасного суспільства полягає в реалізації цінностей, то так звані основні підсистеми суспільства в цілому, що утворюють соціальну реальність, - політика, економіка, наука, культура - лише ціннісні орієнтації Нового Віктимального Порядку. Належність до економіки, політики або мистецтва визначається зовсім не властивостями речей, слів або вчинків, а ставленням до них як до життєво важливого або несуттєвого[11, с. 173].

I хоча концепт віктимального порядку набагато ширший та глибший за концепт радикалізму, виходить далеко за його пізнавальні, описові потенції, претендує на фактор і критерій деконструкції не вельми реальної дійсності у намаганнях іiі нового осмислення (переосмислення), який ще має віднайти свій подальший теоретичний розвиток саме в межах кримінологічної проблематики, вже зараз є всі підстави для твердження, що радикалізм неможливий поза віктимальністю. Бути жертвою (в тому числі й симулятивною, колективною жертвою як симулякром) - така ж необхідність як і наявність зовнішнього об'єкту спрямування надлишкової (не реалізованої) пасіонарності. При цьому такий об'єкт у його конкретних рисах, як нами вже наголошувалось, виконує другорядну роль.

Сценарій «замісної жертви», влучно підкреслює О. М. Аитвинов, подібний до «цапа-відбувайла» і його наслідків. Місце «цапа-відбувайла» й пов'язаного 3 ним ритуалу посідає обрана натовпом жертва, яка виконує замісні функції в цій спільноті[11, c. 168]. Р. Жирар створив концепцію сурогатної (замісної) жертви й концентрує увагу на самій жертві. Він доводить, що на таку жертву переносяться вина i страждання інших людей, і жертва буде заміщати їх замість групи або маси людей. Він вважає це основним принципом дії сучасного суспільства[11, с. 168]. У процесі таких надемоційних вибухів і жаги помсти руйнується все навколо та приносяться в жертву навіть ті, хто спочатку й не вбачався «жертвою». Чи не за таким «сценарієм» відбувалися в Україні події в Одесі 2 травня 2014 року, ромські погроми, злочини «торнадівців»? Ж. Бодрійяр пише, що в таких випадках жертва - це вже не той, кого ми переслідуємо, а той, кого ми оплакуємо. Але це нічого не змінює, тому що він все одно залишається «цапом-відбувайлом»[11, с. 168].

Окрім описаних вище функціональних позицій кримінального радикалізму у категоріально-понятійній матерії кримінології, цілком зрозумілою $є$ його присутність у політичній кримінології, як: 1) політикокримінальний феномен - бунтарська злочинність, злочини у складі натовпу, кримінальний екстремізм, тероризм тощо; 2) у сегментах дослідження агресивно-насильницької (групове порушення громадського порядку, хуліганство, вандалізм тощо), а також молодіжної, професійної, пенітенціарної злочинності.

\section{Висновки}

Підсумовуючи, зауважимо, що кримінальний радикалізм характеризується міжпредметною синтетичністю, наскрізністю щодо понять і категорій кримінології, а головне - кримінологічного мислення. Це зумовлено його (кримінального радикалізму) специфічною гносеологічною роллю в кримінологічній науці і як об'єкта пізнання, i як пізнавальної функції, що реалізується в описі, поясненні особливостей механізму криміногенної детермінації, специфічних рис особистості злочинця й особливостей механізму індивідуальної злочинної поведінки, відтворення окремих видів злочинності.

\section{Аітература}

1. Бандурка О. М., Литвинов О. М. Нові постулати часу в концепції криміно- 
логічної детермінації. ВісникКримінологічної асочіачї Украӥни. 2019. Спецвипуск. С. 155162.

2. Орлов Ю. В. Дискурсивнокомунікативна теорія детермінації злочинності: концептуальні засади формування. Вісник Кримінологічної асочіачії Украӥни. 2017. № 3 (17). С. 23-32

3. Орлов Ю. В. Дискурсивний простір злочинності. Вісник Кримінологічної асоиіацї̈ Украӥни. 2018. № 1 (18). С. 126-136.

4. Орлов Ю. В. Дискурсивноперцептивні механізми детермінації злочинності. ВісникКримінологічної асочіащй України. 2018. № 2 (19). С. 176-184.

5. Сакс О. Чоловік, який сплутав дружину з капелюхом, та інші історії з практики / Пер. з англ. О. В. Опанасенко. К. : Наш формат, 2017. 416 c.

6. Костенко А. Н. Криминальный произвол (социопсихология воли и сознания преступника). К., 1990. 147 с.

7. Костенко А. Н. Социопатия хичности как криминогенный фактор. Наука $i$ правоохорона. 2008. № 1. С. 70-75.

8. Кури Х., Поклад В. І. Проблема изучения преступника как жертвы в современной криминологии // Кримінальна субкультура як фактор злочинності : Кримінологічні дослідження : Вип. 2 / Ауган. гуманіт. центр ; Ауган. держ. ун-т внутр. справ ім. Е. О. Дідоренка. Ауганськ : РВВ АДУВС, 2008. С. 12-18.

9. Smith S. J. Crime, Space and Society. Cambridge : Cambridge University Press, 1986. $316 \mathrm{p}$.

10. Аагода К. О., Орлов Ю. В. Невиконання судового рішення: кримінологічна характеристика та запобігання : монографія / За заг. ред. д-ра юрид наук., проф. О. М. Аитвинова ; Кримінологічна асоціація України. Х. : НікаНова, 2015. 286 с.

11. Аитвинов О. М., Гладкова Е. О. Паноптикон Vol. II, або новий віктимальний порядок. ВісникКримінологічної асоиіачиї Украйни. 2019. Спецвипуск. С. 163-174.

\section{THE PLACE OF CRIMINAL RADICALISM IN THE CONCEPTUAL- CATEGORIAL APPARATUS OF CRIMINOLOGY}

The article is devoted to the analysis of the place of criminal radicalism in the subject-discursive field of criminology. It is emphasized that radicalism is the subject of both the highest abstraction of cognition - philosophical as well as sectoral, designed within the limits of psychology, psychiatry, sociology, political science. For the most part, in these fields of knowledge, radicalism is studied through the phenomena of aggression, its socialization, the psychopathization of the individual, the collective, trans personal states of anxiety, social phobias, and, finally, in political science - as an instrument of struggle for power, of various types of political movements. Criminology, manifesting its interdisciplinary nature, epistemological and synthetic functionality, infiltrates the workings of these sciences, philosophy into its semantic field.

The cross-cutting nature of the phenomenon of radicalism for the whole structure of the subject of criminology has been proved: it is present in the general doctrine of criminogenic determination, the identity of the offender, the mechanism of individual criminal behavior, victimology, as well as in a number of components of the special part of criminology (background, crime, background, crime professional, penitentiary, youth crime, etc.).

The epistemological binary of radicalism is emphasized: it is regarded both as a purely criminal factor and as a mixed criminal-criminal practice factor; both as an object of cognition and as an epistemological tool through which knowledge of the determinative nature of crime, including extra-radical phenomenology, is deepened. The initial theoretical prerequisites for the development of a separate theory of the determination of crime - the theory of radicalization - are proposed. It is argued that without the criminal-radical segment, the discursive-communicative theory of crime determination cannot claim completion. Radicalization theory reveals potentially important (with high heuristic potential) cognitive-logical links with theories of stigma, a number of psychological theories of crime determination

Key words: criminal radicalism, criminology, determination, crime, crime, mechanism, personality. 